\title{
LINGKUNGAN SEBAGAI MEDIA PENDIDIKAN KARAKTER SISWA DI SD ISLAM AL-HUDA GENTENG BANYUWANGI
}

\author{
Ansari \\ Institut Agama Islam (IAI) Ibrahimy Genteng Banyuwangi \\ ansaridosen1@gmail.com
}

\begin{abstract}
ABSTRAK
Lingkungan salah satu media belajar siswa sehingga memiliki nilai-nilai berharga dalam proses pendidikan. Lingkungan sebagai sumber pembelajaran siswa dalam belajar dengan mengambil bahan belajar dari lingkungan, maka kecakapan dan kepandaian siswa dapat dipraktikkan dalam kehidupan bermasyarakat. Salah satu media yang dapat digunakan lingkungan yang ada, seperti yang telah diterapkan di SD Islam Al-Huda Genteng Banyuwangi. Penelitian ini dilakukan di SD Islam Al-Huda Genteng Banyuwangi. Metode penelitian yang digunakan deskriptif kualitatif. Data dikumpulkan dengan menggunakan metode observasi, wawancara, dan dokumentasi. Data yang terkumpul berupa kata-kata dianalisis dengan menggunakan teknik deskriptif kualitatif. Hasil penelitian yang diperoleh menunjukkan bahwa ada dua jenis lingkungan yang dapat membentuk pendidikan karakter, yaitu lingkungan alam dan lingkungan sosial. Lingkungan alam digunakan sebagai media pembentuk pendidikan karakter siswa melalui kegiatan Ekstrakurikuler, sedangkan lingkungan sosial melalui kegiatan Kewirausahaan. Perencanaan kegiatan Ekstrakurikuler dilakukan secara bersama dengan seluruh pendidik, sedangkan perencanaan Kewirausahaan dilakukan melalui rapat mingguan bersama guru di sekolah. Hasil pendidikan karakter yang dapat diperoleh dari lingkungan alam melalui kegiatan Ekstrakurikuler adalah disiplin, cinta alam, komunikatif dan bersyukur. Sedangkan pendidikan karakter yang diperoleh dari lingkungan sebagai media melalui kegiatan Kewirausahaan adalah percaya diri, kreatif, dan jujur.
\end{abstract}

\section{Kata Kunci : Lingkungan, Pedidikan Karakter Siswa}

\section{PENDAHULUAN}

Akhir-akhir ini sudah terjadi dengan perubahan nilai-nilai seorang siswa terhadap gurunya mulai dari norma-norma yang diterapkan di sekolah sudah tidak di perhatikan lagi, dengan begitu canggihnya sebuah kemajuan teknologi yang harus di antisipasi oleh semua guru mapun pendidik di sekolah. Hal ini, akan menimbulkan hilangnya nilai dan moral yang baik dalam kehidupan masyarakat baik secara pribadi maupun secara bermasyarakat. Perubahan nilai atau norma karena disebabkan beberapa faktor; pertama, nilai budaya bermasyarak mulai pudar kedua, nilai kebersamaan dan salaling menghormati sesama sudah mulai pudar bahkan hingga jati diri bangsapun mulai hilang oleh arus perkembangan teknologi. Dengan kemajuan teknologi banyak anak bangsa yang menjadi taruhannya karena melupakan karakter bangsa itu sendiri, lebih memilih meniru gaya dan tingkah laku kebudayaan bangsa lain dibanding dengan budaya bangsa sendiri. Dalam UUD 1945 yang berbunyi "mengantarkan rakyat Indonesia ke dpan pintu gerbang kemerdekaan Negara Indonesia yang merdeka, bersatu, berdaulat, adil dan makmur". ${ }^{1}$

\footnotetext{
${ }^{1}$ Fadillah Mohammad \& Mualifatul Khorida Lilif, Pendidikan Karakter Untuk Anak Usia Dini (Jogjakarta: ArRuzz Media, 2013), 24.
} 
Pendidikan karakter diharapkan mampu sebagai solusi dan sebagai transformasi yang baik dalam menumbuhkan karakter positif serta membentuk akhlak mulia anak agar menjadi lebih baik. bahkan upaya-upaya yang dilakukan oleh pemerintah untuk mengatasi maslahmasalah tersebut salah satunya, menerapkan pendidikan karakter di sekolah-sekolah. Hal ini sudah mejadi aturan dalam UU Nomor 29 Tahun 2003 tentang Sistem Pendidikan Nasional menegaskan yaitu. ${ }^{2}$

"Pendidikan nasional berfungsi mengembangkan kemampuan dan membentuk watak serta peradaban bangsa yang bermartabat dalam rangka mencerdaskan kehidupan bangsa, bertujuan untuk berkembangnya potensi peserta didik agar menjadi manusia yang beriman dan bertakwa kepada Tuhan Yang Maha Esa, berakhlak mulia, sehat, berilmu, cakap, kreatif, mandiri dan menjadi warga negara yang demokratis serta bertanggung jawab".

Berangkat dari hal diatas, untuk mencegah krisis akhlak yang semakin parah, di sekolah-sekolah saat ini sudah mulai diterapkan pendidikan karakter Seperti yang telah diterapkan di SD Islam Al-Huda Genteng Banyuwangi SD Islam Al-Huda merupakan sekolah dasar Islam yang menekankan pendidikan karakter dalam pembelajarannya. Bahkan karakter tidak hanya di sisipkan dalam kegiatan belajar mengajar, melainkan juga dengan melalui kegiatan-kegiatan positif setiap harinya, selain itu juga dilakukannya pembiasaanpembiasaan yang bersifat positif Berdasarkan hasil wawancara dengan ustad Anam, selaku wali kelas 3 mengatakan bahwa:

"Pendidikan karakter merupakan bekal hidup anak di masyarakat nantinya agar ketika mereka dewasa dapat berakhlak yang mulia. Karakter manusia memang harusnya ditanamkan sedini mungkin, apalagi sekarang ini anak-anak sudah banyak yang berperilaku menyimpang. Seperti berkata kotor dan berperilaku tidak sopan. Sehingga di sekolah ini sangat menekankan karakter pada peserta didik. Banyak kegiatankgiatan di luar kelas yang dilakukan dengan tujuan membentuk karakter siswa". ${ }^{3}$

Selain dari pendapat guru, pihak kaur kesiswaan sekolah juga mengatakan betapa pentingnya pendidikan karakter bagi siswa, sebagaimana hasil wawancara dengan pihak kesiswaan yang mengungkapkan bahwa:

"Sekolah ini merupakan sekolah alam yang sangat menekankan pendidikan karakter pada siswa Karakter siswa kita bentuk sejak usia dini, di sini pembelajaran sebagian besar dilakukan di luar kelasagar siswa lebih mengenal lingkungan dan dapat menghargai lingkungan sekitar Karakter tidak bisa kita bentuk hanya dengan bekal teori, tetapi akhlak guru merupakan salah satu contoh dan panutan siswa untuk dapat ditiru Pembiasaan positif juga sangat berpengaruh dalam pembentukan karakter Dapat dilihat darivisi misi sekolaih ini dimana sekolah ini sangat menjunjung tingi pendidikan karakter"4

Karakter hanya akan menjadi sebuah wacana jika tidak tepat penyampaian serta penanamannya dalam diri siswa. Sehingga diperlukan media yang tepat dalam penyampainnya agar karakter dapat benar-benar terbentuk seperti yang diharapkan. Salah

\footnotetext{
${ }^{2}$ UU Nomor 29 Tahun 2003 tentang Sistem Pendidikan Nasional.

${ }^{3}$ Hasil wawancara dengan ustad Anam (Wali Kelas 3). 14 Juli 2019 Jam 10.00 WIB

${ }^{4}$ Hasil wawancara dengan Kaur Kesiswaan SD Islam Al-Huda Genteng Banyuwangi 14 Juli 2019 Jam 10.00 WIB
} 
satunya media yang dapat diterapkan untuk siswa yaitu lingkungan. Lingkungan sebagai media, siswa akan turut aktif dalam berbagai kegiatan secara langsung yang diharapkan menjadi suatu kebiasaan baik untuk bekal hidupnya di masa datang. Tanpa disadari siswa, mereka melakukan kegiatan-kegiatan yang sebenarnya ditujukan untuk menanamkan karakter pada dirinya sehingga karakter siswa tumbuh dan sesuai dengan harapan.

Pendidikan karakter merupakan bekal hidup anak di masyarakat nantinya agar ketika mereka dewasa dapat berakhlak yang mulia. Karakter manusia memang harusnya ditanamkan sedini mungkin, apalagi sekarang ini anak-anak sudah banyak yang berperilaku menyimpang. Seperti berkata kotor dan berperilaku tidak sopan Sehingga di sekolah ini sangat menekankan karakter pada siswa. Banyak kegiatan-kgiatan di luar kelas yang dilakukan dengan tujuan membentuk karakter siswa.

Adapun SD Islam Al-Huda Genteng Banyuwangi merupakan sekolah alam yang sebagian besar kegiatannya dilakukan di luar kelas. Sehingga lingkungan sangat berpengaruh besar dalam kegiatan belajar mengajar dan juga proses pembentukan karakter siswa. Sekolah ini berada dalam ruang lingkup yayasan Pondok Al-Huda. Kegiatan-kegiatan yang dilakukan di sekolah juga berdasarkan nilai-nilai Islami. Sekolah ini memiliki banyak kegiatan menarik yang ditujukan untuk membentuk karakter siswa. Terlebih lagi sekolah ini jauh dari keramain kota sehingga dapat menciptakan suasana sekolah yang nyaman.

Lingkungan sebagai media pembelajaran bagi siswa dalam menumbuhkan karakter serta berinteraksi langsung dengan lingkungan, sehingga para siswa akan lebih tertarik untuk belajar dalam memanfaatan lingkungan untuk membentuk karakter siswa, guru sangat berharap para siswa akan lebih akrab dengan lingkungan, sehingg dapat menumbuhkan rasa saling percaya diri dan cinta akan lingkungan sekitarnya. Dengan adanya kegiatan yang dilakukan di lingkungan sekitar, diharapkan dapat meningkatkan kreativitas dan aktivitas siswa.

\section{METODE PNELITIAN}

Penelitian ini menggunakan metode penelitian kualitatif dengan jenis penelitian deskriptif; yaitu suatu penelitian untuk mendeskripsikan secara sistematis, ${ }^{5}$ faktual dan akurat sedangkan analisis data tidak keluar dari tema yang menjadi penelitian. Peneliti menggunakan pendekatan empiris sosiologis sebuah kajian lingkungan sebagai media pendidikan karakter siswa di SD Islam Al-Huda Genteng Banyuwangi. Teknik pengumpulan data $^{6}$ menggunakan tiga cara: Pertama, observasi, peneliti mengamati proses lingkungan serta mengamati karakter siswa di SD Islam Al-Huda Genteng Banyuwangi. Observasi ini sangat cocok digunakan dalam melihat karakter siswa karena karakter siswa tidak dapat dilihat secara tertulis, melainkan harus dengan pengamatan secara langsung. Kedua, wawancara dengan menggali bagaimana lingkungan sebagai media dalam membentuk pendidikan karakter siswa melalui kegiatan Ekstrakurekulir dan Kewirausahaan. Ketiga, dokumentasi yang berupa profil sekolah, struktur organisasi, silabus perencanaan kegiatan, foto berbagai kegiatan yang ada. ${ }^{7}$

\footnotetext{
${ }^{5}$ Jusuf Soewadji, Pengantar Metodologi Penelitian, Jakarta: Mitra Wacana Media, 2012, 52.

${ }^{6}$ Darmadi Hamid, Metode Penelitian Pendidikan, (Pontianak: Alfabeta, 2011), 17.

${ }^{7}$ Moleong Lexy, Metode Penelitian Kualitatif (Bandung: PT. Remaja Rosda Karya, 2002), 248.
} 


\section{HASIL PENELITIAN}

Di SD Islam Al-Huda Genteng Banyuwangi, lingkungan sering digunakan dalam pembentukan karakter siswa Pembentukan karakter siswa dengan menggunakan media lingkungan sering dilaksanakan pada hari sabtu. Khusus hari sabtu adalah hari yang diperuntukkan untuk mengembangkan karakter dan kreativitas siswa, sehingga hari sabtu disebut dengan hari berwirausaha.

Ada dua jenis lingkungan yang digunakan sebagai media pembentukan karakter siswa, yaitu lingkungan alam dan lingkungan sosial Lingkungan alam digunakan sebagai media pembentuk karakter siswa dalam kegiatan Ekrakurekulir Sedangkan lingkungan sosial digunakan sebagai media pembentuk karakter siswa dalam kegiatan Wirausaha Keterangan tersebut diperoleh dari hasil wawancara dengan pihak kesiswaan sebagai berikut:

"Hari sabtu di sini di sebut dengan berwirausaha, Wirausaha ini berisi kegiatankegiatan yang dilakukan untuk membentuk karakter siswa Cara yang menurut kami efektif dalam membentuk karakter siswa yaitu dengan cara lingkungan alam di sekitar sekolah, maupun di luar sekolah, selain itu juga kita manfaatkan lingkungan sosial atau lingkungan msyarakat sebagai medianya Pemilihan lingkungan sebagai media ditujukan agar siswa bisa mendapat pengalaman langsung Kita harapkan dengan begini karakter yang ingin ditanamkan akan lebih mudah tersamapaikan" 8

Dari hasil wawancara di atas, berikut merupakan perencanaan, pelaksanaan dan hasil karakter siswa dalam memanfaatkan lingkungan sebagai media pembentukan karakter siswa melalui kegiatan Ekrakurekulir dan Kewiirausahaan.

\section{Perencanaan Lingkungan Sebagai Media Pendidikan Karakter Melalui Ekstrakurikuler dan Kewirausahaan Kegiatan di SD Islam Al-Huda Genteng Banyuwangi}

Dari hasil wawancara dan dokumentasi diperoleh data-data tentang perencanaan kegiatan pemanfaatan lingkungan sebagai pembentuk karakter siswa melalui kegiatan Ekstrakurikuler dan Kewirausahaan. Berikut adalah perencanaan kegiatan yang dilakukan dalam memanfaatkan lingkungan untuk membentuk karakter siswa:

\section{Ekstrakurikuler}

Ekstrakurikuler adalah kegiatan pengembangan diri dengan dua tema, yaitu Tsaqofiyah dan Jasadiyah Materi dari tema Tsaqofiyah secara garis besar adalah membentuk siswa menjadi pribadi muslim sesuai dengan Al Qur'an dan Hadits. Sedangkan tema Jasadiyah merupakan pengembangan keterampilan siswa secara fisik, yang di dalamnya terdapat materi-materi pramuka seperti materi pramuka pada umumnya, tetapi dalam penyampaiannya akan dikembangkan dan dikaitkan dengan nilai-nilai agama Islam.

Kegiatan ini hampir sama dengan kegiatan-kegiatan pramuka yang di laksanakan di sekolah-sekolah, akan tetapi ada perbedaan dalam aplikasinya dilapangan yang isi materi di sesuaikan dengan lingkungan sekitar yaitu pondok pesantren yang ruang lingkupnya Islami. Hal ini dikarenakan SD Islam Al-Huda Genteng Banyuwangi merupakan sekolah yang berada dalam lingkup Pesantren sehingga perencanaannya juga di sesuaikan dengan

\footnotetext{
${ }^{8}$ Hasil wawancara dengan Kaur Kesiswaan SD Islam Al-Huda Genteng Banyuwangi 9 Juli 2019 Jam 10.00 WIB
} 
karakteristik lingkungan Nilai-nilai karakter yang ditanamkan kepada siswa dengan melalui kegiatan Ekstrakurikuler yaitu pentingya disiplin, bersyukur, cinta alam serta komunikatif. Sedangakan media yang akan digunakan dalam melaksankan kegiatan yaitu lingkungan sekolah sebagai objek perkenalan pada siswa sehingga para siswa dapat mencermati dan belajar dengan sungguh-sungguh dan penuh dengan rasa keakraban. Hal ini diungkpakan oleh pembina Ekstrakurikuler.

"Sebenarnya Ekstrakurikuler ini sama dengan pramuka yang ada di sekolah lain, hanya saja di sini materinya ditambah dan dikaitkan dengan agama Islam, agar nilainilai agama tetap tersampaikan dalam segala hal. Untuk kegiatan Ekstrakurikuler ini memang ada perencanaan khusus yang sudah ditetapkan oleh seluruh sekolah dalam yayasan Pondok Al-Huda, setiap sekolah dalam naungan Pondok Al-Huda akan melakukan rapat untuk membahas program Ekstrakurikuler dan program kegiatan lainnya. Rapat ini diadakan dengan tujuan pelaksanaanya berjalan sesuai dengan rencana Jadi melihat kondisi anak-anak juga agar anak-anak tertarik dalam mengikuti kegiatan"9

Dilihat dari penjelasan Pembina Ekstrakurikuler, telah dijelaskan bahwa kegiatan ini dirancang perencanaannya Tetapi dalam prakteknya Pembina Ekstrakurikuler akan mengembangkan sendiri sesuai dengan kemampuan dan keadaan siswa pada saat kegiatan berlangsung agar kegiatan lebih menarik.

Sedangakan media yang akan dipakai dalam pelaksanaannya adalah media lingkungan alam yang ada di sekitar sekolah. Lingkungan yang ada di sekolah akan menjadi objek pengamatan siswa, sehingga siswa dapat belajar dengan melihat secara langsung.

\section{Kewirausahaan}

Kewirausahaan adalah kegiatan jual beli atau bazar yang secara khusus diadakan di sekolah dalam rangka mengembangkan kreativitas siswa. Kewirausahaan diikuti oleh seluruh siswa di SD Islam Al-Huda Genteng Banyuwangi. Kegiatan ini merupakan program mingguan sekolah. Kegiatan ini dihasilkan dari rapat mingguan guru yang rutin dilakukan dalam rapat mingguan akan membahas tentang kegiatan yang dilaksanakan pada hari sabtu Usulan-usulan dari semua pihak guru berkenaan dengan kegiatan yang dapat dilakukan untuk mengisi Kewirausahaan akan ditampung dan didiskusikan secara bersama. Dari hasil diskusi tersebut maka pihak kesiswaan akan menentukan jenis kegiatan yang akan dilaksanakan.

"Kegiatan Kewirausahaan diadakan oleh pihak sekolah Sebelum pelaksanaan kegiatan, tidak ada perencanaan khusus secara tertulis dari pihak kesiswaan Namun pada awal minggu akan dibahas bersama-sama dengan ustadz dan ustadzah selaku pengajar di sekolah berkaitan dengan kegiatan apa yang akan dilakukan untuk mengisi Kewirausahaan. Untuk kegiatan wirausaha yang akan dilaksanakan ini, guru menjelaskan bentuk kegiatannya pada siswa tiga hari sebelum pelaksanaan Untuk pelaksanaannya sendiri pada jam 09.00 dihari sabtu Nanti anak-anak yang akan berjualan sudah diperintahkan untuk menata barang-barangya di meja yang telah disediakan Karena yang berjualan hanya satu kelas, maka untuk siswa dari kelas yang lain harus menunggu di kelas masing-masing terlebih dahulu Setelah semua sudah

\footnotetext{
${ }^{9}$ Hasil wawancara dengan Pembina Ekstrakurikuler SD Islam Al-Huda Genteng Banyuwangi 9 Juli 2019 Jam $10.00 \mathrm{WIB}$
} 
siap, maka market dibuka dan yang lain diperbolehkan untuk keluar kelas membeli barang yang dijual temannya Lalu Kewirausahaan akan ditutup pukul 945 dan semua diharapkan masuk kelas didampingi wali kelas masing-masing. Di dalam kelas ustadz atau ustadzah selaku wali kelas bersama dengan siswa akan mengevaluasi bersama tetang kegiatan yang telah dilaksanakan Siswa juga diberi arahan tentang karakter yang tersirat dari kegiatan tadi" 10

Tujuan dalam melaksanakan kegiatan ini yaitu untuk melatih siswa dalam berwirausaha agar siswa mempunyai bakat dan minat dalam menentukan kepribadiannya disamping itu dalam rangka membentuk karakter siswa dan membangkitkan kreatifitasnya untuk mendukung kemampuan dalam belajar dikelas.

"Kewirausahaan ini seperti bazaar-bazar yang sering kita ketahui, tapi ya di sini yang jualan anak-anak, bukan gurunya Diadakannya Kewirausaan ini untuk melatih rasa percaya diri dan meningkatkan kreativitas siswa Bisa juga untuk melatih kejujuran siswa, karena sebagai pembeli harus jujur ketika membanyar walaupun keadaannya ramai Kalau mereka berani berjualan maka akan menambah kepercayaan dirinya, makanya di sekolah ini banyak kegiatan-kegiatan seperti ini, jadi tiap minggunya ya ganti-ganti kegiatannya"11

Pembentukan karakter sesuai dengan visi dan misi sekolah Hal ini dikarenakan pihak sekolah ingin menyelamatkan generasi bangsa di masa yang akan datang. ${ }^{12}$

\section{Pelaksanaan Lingkungan Sebagai Media Pendidikan Karakter di SD Islam Al-Huda Genteng Banyuwangi}

a. Ekstrakurikuler

Kegiatan Ekstrakurikuler diikuti oleh seluruh siswa kelas III, IV dan V Kegiatan ini dilaksanakan mulai dari pukul 08.00 sampai dengan pukul 09.00. Selama kegiatan ada Pembina khusus yang mendampingi Kegiatan Ekstrakurikuler bertujuan untuk membentuk karakter disiplin, syukur, cinta alams erta komunikatif pada diri siswa.

Pada pertemuan tanggal 10 Juli 2019 kegiatan Ekstrakurikuler dilaksanakan pada pukul 08.00 Tampak siswa sudah mulai berkumpul di halaman sekolah untuk mengikuti kegiatan Ekstrakurikuler Padamulanya, siswa berbaris dengan rapi dan berdo'a bersama di halaman sekolah. Setelah berdo'a, maka kegiatan dilanjutkan dengan pemberian materi tentang makna dari surat Al-'Alaq. Pembina Ekstrakurikuler menjelaskan bahwa kata Iqro' dalam surat Al-'Alaq mengandung arti "Bacalah”, membaca yang dimaksud bukan hanya membaca tulisan-tulisansaja, melainkan juga dapat dimaknai membaca lingkungan sekitar. Sebagai manusia sudah seharusnya dapat memahami lingkungan agar tidak bertindak melampaui batas. Dengan memahami keadaan Lingkungan sekitar, makaakan membuat manusia dapat selalu bersyukur atas segala yang telah dimiliki. ${ }^{13}$

Materi kedua adalah penjelasan tentang lingkungan sekitar dan dimulai dari lingkungan sekolah yang paling dekat dengan kita. Siswa diminta untuk menyebutkan segala

\footnotetext{
${ }^{10}$ Hasil wawancara dengan Kaur Kesiswaan SD Islam Al-Huda Genteng Banyuwangi 9 Juli 2019 Jam 11.00 WIB

${ }^{11}$ Hasil wawancara dengan Kaur Kesiswaan, 0 Juli 2019, Jam 11.00 WIB.

12 Dokumen SD Islam Al-Huda Genteng Banyuwangi.

${ }^{13}$ Observasi SD Islam Al-Huda Genteng Banyuwangi
} 
sesuatu yang ada di sekolah. Siswa secara bergantian menyebutkan kata kelas, aula, tempat parkir, kamar mandi, kantin dan lain sebagainya. Selanjutnya pembina menjelaskan bahwa kata Iqro' dapat dipahami bahwa kita harus dapat memahami keadaan lingkungan sekitar, dan dimulai dari lingkungan yang paling dekat dengan kita. Pada pertemuan ini, Pembina juga menjelaskan bahwa lingkungan yang ada di sekolah akan digunakan sebagai media pengamatan agar siswa dapat ikut menjaganya.

Untuk melihat tingkat pemahaman siswa, Pembina memberikan tugas sebagai latihan Tugas yang diberikan ada dua macam, yang pertama adalah siswa diminta untuk menjelaskan kembali makna dari surat Al-'Alaq yang telah disampaikan. Sedangkan tugas yang kedua adalah siswa diminta untuk mengamati lingkungan di sekitar sekolah sebagai aplikasi dari makna kata Iqro' yang tertulis dalam suratAl-'Alaq ayat pertama. Ketika siswa menemui halhal yang tidak sesuai maka siswa diminta untuk memberikan solusinya.

Penjelasan tentang tugas yang harus dikerjakan telah dipahami siswa. Pembina memberikan waktu 30 menit untuk mengerjakannya secara berkelompok. Masing-masing kelompok terdiri dari enam sampai tujuh siswa. Terdapat ketentuan Khusus dalam menentukan kelompok, yaitu untuk siswa putra dan putri tidak diperbolehkan bergabung dalam satu kelompok. Hal ini guna untuk menanamkan sikap syukur siswa, Bahwa dalam Islam ada ketentuan batasan antara laki-laki dan perempuan yang bukan muhrim. Selaini tu, siswa juga diberi kebebasan untuk mengerjakan di tempat yang menurut mereka nyaman ${ }^{14}$

Dari hasil tugas siswa, didapatkan hasil bahwa manusia merupakan makhluk ciptaan Allah SWT yang diciptakan dari benda yang hina kemudian memuliakannya dengan mengajar membaca, menulis dan memberi ilmu pengetahuan, tetapi banyak makhluk yang lalai dan terlena oleh dunia sehingga mereka tidak bersyukur atas nikmat Allah. Materi surat Al-Alaq merupakan kelanjutan dari materi yang telah dijelaskan pada pertemuan sebelumnya, sehingga siswa tidak merasa kesulitan dalam mengerjakan.

Sedangkan dari hasil pemngamatan yang dilakukan di lingkungan sekolah, siswa mendapatkan berbagai macam pendapat, seperti kelompok putra yang menjelaskan keadaan taman, mereka berpendapat bahwa tanaman yang terletak di depan kantor beberapa sudah kering pertanda bahwa tanaman tersebutt idak disiram secara rutin. Mnurut mereka seharusnya tanaman harus selalu rutin disiram agar tidak mati.

Waktu tersisa10 menit, semua kelompok telah menyampaikan hasil pengamatan dan pendapatnya. Pembina bersama-sama mengambil kesimpulan bahwa menjaga lingkungan sekitar merupakan hal yang sangat penting. Dengan menjaga lingkunga maka kita akan terhindar dari berbagai penyakit seperti diare dan demam berdarah. Semua orang berkewajiban untuk menjaga lingkungan. Diharapkan dari kegiatan pengamatan yang dilakukan siswa dapat lebih peka dan mencintai lingkungan sekitar sehingga merasa ikut bertanggung jawab untuk menjaga kelestariannya. Tepat pukul 09.00 dalam kegiatan Ekstrakurikuler diakhiri dengan berbaris dan berdo'a bersama. ${ }^{15}$

Pemanfaatan lingkungan sebagai media dapat dilihat dari hasil wawancara dengan Pembina Ekstrakurikuler sebagai berikut: ${ }^{16}$

\footnotetext{
${ }^{14}$ Observasi SD Islam Al-Huda Genteng Banyuwangi

15 Observasi SD Islam Al-Huda Genteng Banyuwangi

${ }^{16}$ Wawancara dengan Pembina Ekstrakurikuler SD Islam Al-Huda Genteng Banyuwangi
} 
"Pada pertemuan kali ini saya memanfaatkan lingkungan sekolah sebagai media, kalau biasanya media yang digunakan adalah gambar, kartu, atau video, maka saya kali ini lebih memilih untuk mengguakan lingkungan sebagai medianya. Anak-anak saya ajak untuk melihat keadaan sekitar, dan mencari apa yang tidak sesuai. Dengan membawa siswa melihat langsung keadaan sekitar, maka siswa akan lebih peka terhadap lingkungannya. Karena mereka dapat berinteraksi dengan lingkungan sehingga mereka bisa mendapat pengalaman belajar secara langsung"

Sedangkan kaitan antara materi dengan surat Al-Alaq dijelaskan oleh Pembina Ekstrakurikuler sebagai berikut: ${ }^{17}$

"Materi yang kita pelajari adalah tentang masalah yang ada di masyarakat, tapi untuk kali ini anak-anak tidak dibawa kemasyarakat yang ada diluar, karena keterbatasan waktu Jadi siswa kita ajak untuk mengamati lingkungan yang ada di sekolah, kita manfaatkan lingkungan yang terdekat terlebih dahulu, siswa mengamati dan Menemukan masalah atau halyang tidak sesuai dengan yang seharusnya. Pengamatan yang dilakkan siswa itu dapat diartikan sebagai Iqro', selain itu juga menanamkan pada siswa agar selalu menjaga lingkungan sekitar dan mensyrukurinya".

Menurut pembina Ekstrakurikuler, karakter-karakter yang ditanamkan dalam kegiatan-kegiatan seperti ini diharapkan dapat terus tertanam pada diri siswa sehingga dapat terbawa ketika siswa hidup bermasyarakat.

\section{b. Kewirausahaan}

Kewirausahaan dilaksanakan pada hari Sabtu tanggal 17 Juli 2019 mulai dari pukul 09.00 sampai dengan pukul 09.45. Kegiatan ini dilaksanakan oleh semua siswa dari kelas I sampai VI Khusus untuk kelas II pada pertemuan kali ini mendapat giliran sebagai penjual sedangkan kelas yang lain sebagi pembeli. Sebelum Kewirausahaan dimulai, siswa bersama dengan guru menyiapkan tempat untuk menata barang-barang yang akan dijual oleh siswa kelas II. Mereka menata meja dan beberapa kursi di sepanjang teras kelas II. Setelah meja dan kursis sudah tertata rapi, siswa kelas II menata barang-barang yang akan dijual. Mereka menjual berbagai makanan dan minuman seperti snack, aneka jus, minuman kemasan, pudding, serta coklat yang menarik. ${ }^{18}$

Selama kegiatan Kewirausahaan, siswa yang tidak menjadi penjual juga tidak kalah antusias dalam mengikuti kegiatan ini. Mereka berkelililng melihat-lihat berbagai makanan dan minuman yang dijual oleh teman-teman mereka. Mereka terlihat memilih-milih makanan dan minuman yang sudah disediakan penjual bahkan tidak sedikit pula siswa yang membeli lebih dari satu jenis makanan atau minuman. Suasana selama kegiatan Kewirausahaan sangat meria, ramai, serta menyenangkan. Siswa terlihat berdesakan untuk membeli makanan dan minuman.

Menurut siswa kelas II selaku penjual, mereka merasa sangat senang mengikuti kegiatan ini karena biasanya dirumah mereka hanya bisa bermain jual beli dengan temantemannya tetapi sekarang bisa merasakan menjadi penjual yang sesungguhnya. Sehingga

\footnotetext{
${ }^{17}$ Wawancara dengan Pembina Ekstrakurikuler SD Islam Al-Huda Genteng Banyuwangi

${ }^{18}$ Observasi SD Islam Al-Huda Genteng Banyuwangi
} 
mereka sangat bersemangat dalam menjajakan dagangannya, seperti dengan berkata "Kuenya-kuenya, Cuma 500 saja, ayo silahkan dibeli"19

Menurut keterangan guru Salsabila selaku pengajar Aqidah, kegiatan ini ditujukan untuk melatih siswa melakukan kegiatan jual beli dengan baik dan benar, serta dapat membentuk karakter percaya diri dan jujur halini dijelskan dalam wawancara sebagai berikut:

"Dari kegiatan ini diharapkan siswa dapat lebih berani dan jujur karena sebagai penjual mereka dituntut untuk berani menjajakan barang dagangan mereka. Sedangkan bagi pembeli mereka harus bersikap jujur selama melakukan transaksi jual beli. Mengingat ramainya siswa yang membeli maka mereka diharapkan jujur untuk membayar sejumlah barang yang dibeli". ${ }^{20}$

Dari pengamatan yang dilakukan, tidak terlihat pembeli yang mengambil barang tanpa membayarnya. Mereka semua tertib, antri dan menanyakan harga barang ketika mereka suka dengan makanan atau minuman yang dijualdan harganya sesuai dengan uang yang dimiliki maka mereka langsung membelinya. Selain untuk melatih siswa bersikap percaya diri dan jujur kegiatan ini juga dapat menjadi media pembelajaran siswa, hal ini dikarenakan dalam Pembelajaran dikelas III terdapat materi pelajaran tentang kegiatan jual beli. ${ }^{21}$

Kegiatan Kewirausahaan ini merupakan salah satu bentuk memanfaatkan lingkungan masyarakat secara tidak langsung, medianya adalah lingkungan sosial. Siswa belajar mengenal kegiatan dalam masyarakat dengan cara meniru kegiatan tersebut di lingkungan sekolah. Pihak sekolah sengaja membentuk suasana sekolah serupa dengan lingkungan masyarakat agar lebih terasa natural. Siswa melakukan jual beli seperti kegiatan jual beli yang ada di lingkungan masyarakat Kewirausahaan termasuk dalam Klasifikasi media pengalaman tiruan yaitu siswa memperoleh pengalaman melalui benda-benda atau kejadiankejadian tiruan yang sebenarnya.

\section{Hasil Pendidikan Karakter Siswa Melalui Kegiatan Ekstrakurikuler dan Kewirausahaan}

Dari berbagai kegiatan yang telah dilakukan di lingkungan sekolah, tentu ada tujuan tertentu Tujuan tersebut adalah untuk membentuk karakter siswa di SD Islam Al-Huda Genteng Banyuwangi dapat dikatakan berbagai kegiatan yang dilakukan merupakan salah satu tahap untuk membentuk karakter siswa. Hasil dari karakter yang diharapkan tentu tidak dapat dilihat secara tertulis seperti kita melihat hasil nilai ujian tulis. Hal ini dijelaskan oleh Ustadzah A’yun selaku wali kelas IV di SD Islam Al-Huda Genteng Banyuwangi:

"Tentu sangat berpengaruh dalam hal karakter siswa, karena dapat dibilang bahwa adanya kegiatan seperti Ekstrakurikuler dan Kewirausahaan merupakan bentuk kegiatan yang ditujukan untuk membentuk karakter siswa. Karena kegiatan tersebut rutin dilakukan dapat dilihat dari adanya perubahan sikap siswa dari hari ke harinya. Dulu awala-awal mereka masuk di sekolah masih banyak anak yang perilakunya bisa dibilang nakal tapi lama-lama sifat dan sikap mereka dapat berubah jadi lebih baik, seperti dulu itu anak-anak masih suka clometan ketika jam pelajaran, trus juga mereka

\footnotetext{
${ }^{19}$ Observasi SD Islam Al-Huda Genteng Banyuwangi

${ }^{20}$ Wawancara dengan Guru Salsabila (Guru Aqidah) di SD Islam Al-Huda Genteng Banyuwangi pada Tanggal 17 Juli 2019 Jam 09.30 WIB.

${ }^{21}$ Observasi SD Islam Al-Huda Genteng Banyuwangi
} 
takut untuk bertanya, malu-malu. Tapi sekarang bisa dibilang sudah tidak ada lagi siswa yang seperti itu, banyak kemajuan yang dialami oleh siswa". ${ }^{22}$

Selain untuk membentuk karakter siswa, pemanfaatan lingkungan sekolah dengan mengadakan berbagai kegiatan juga dapat menjadi penyegar otak siswa yang jenuh dengan kegiatan belajar mengajar selama lima hari. Karena kegiatan yang diadakan sangat menarik dan disesuaikan dengan karakter siswa SD yang aktif dan suka bermain Sehingga tujuan yang akan dicapai melalui berbagai kegiatan dalam Kewirausahaan ini lebih mudah tersampaikan. Hal ini dikarenakan siswa melakukannya dengan rasa senang, selain itu siswa dapat selalu mengingat pengalaman belajarnya.

Diharapkan dari kegiatan Kewirausahaan siswa dapat menanamkan sikap percaya diri, kreatif, dan jujur Hal ini disebabkan karena selama kegiatan mereka harus dapat memberanikan diri untuk menjajakan makanan yang dijual pada pembeli Jika mereka malumalu maka tidak akan banyak pembeli yang terterik untuk membeli makanan atau minuman yang dijual.

Hasil karakter tersebut dapat dilihat dari proses kegiatan belajar mengajar yang terjadi, siswa selalu aktif dan percaya diri. Mereka tidak malu-malu bertanya pada Ustadz dan Ustadzah yang mengajar. Ketika akan bertanya, siswa mengangkat tangan terlebih dahulu kemudian mereka satu persatu bergantian bertanya tentang materi yang diajarkan Selain itu selama proses belajar mengajar ketika Ustadz dan Ustadzah sering memberi pertanyaan secara lisan maka siswa secara berebut mengacungkan tangan dan menjawabnya Hal ini dipaparkan oleh ustadzah A'yun dalam wawancara:

"Saya itu sering memberi anak-anak pertanyaan secara lisan Biar anak-anak belajar untuk percaya diri dan komunikatif, dan terbukti lho mbak, kalau saya kasih pertanyaan anak-anak berebut menjawab kayak yang tadi mbak lihat di kelas Entah salah atau benar mereka berani untuk menjawab Terkadang anak yang tidak mendapat kesempatan menjawab itu malah minta dikasi pertanyaan, katanya biar gak kalah sama teman- temannya". ${ }^{23}$

Kekreatifan siswa juga tampak dari berbagai hasil karya mereka, dalam pelajaran kesenian siswa sering membuat berbagai karya dari barang-barang bekas Barang bekas tersebut dibentuk menjadi kerajianan yang menarik seperti bingkai foto, gambar yang terbentuk dari biji-bijian, dan lain sebagainya. ${ }^{24}$

Dalam kegiatan pembelajaran sehari-hari, siswa dibiasakan untuk jujur dalam segala hal, termasuk juga jujur ketika mengerjakan tugas harian. Berapapun nilai yang mereka dapat akan lebih berharga jika nilai tersebut adalah hasil murni dapi pikiran masing-masing. Selama kegiatan berlangsung, guru selalu memberikan tugas mandiri kepada siswa sebagai latihan dan mengukur pemahaman siswa terhadap materi Siswa dengan tertib mengerjakan tanpa melihat jawaban dari teman. Walaupun masih ada beberapa dari siswa yang ingin melihat

\footnotetext{
${ }^{22}$ Wawancara dengan Ustadzah A'yun (Wali Kelas IV SD Islam Al-Huda) Tanggal 17 Juli 2019 jam 11.00 WIB

${ }^{23}$ Wawancara dengan Ustadzah A'yun (Wali Kelas IV SD Islam Al-Huda) Tanggal 17 Juli 2019 jam 11.00 WIB

${ }^{24}$ Observasi SD Islam Al-Huda Genteng Banyuwangi
} 
jawaban milik temannya tetapi teman yang lain berusaha mengingatkan agar tidak mencontek. $^{25}$

Sedangkan dari Kegiatan Ekstrakurikuler yang diadakan setiap hari sabtu di SD Islam Al-Huda Genteng Banyuwangi dapat membentuk karakter siswa untuk lebih disiplin, syukur, cinta alam dan komunikatif. Hasil karakter ini dapat dilihat dari pengamatan yang dilakukan Pada pagi hari siswa tidak ada yang tampak terlambat masuk kelas dan mereka sudah ada di kelas sebelum bel masuk berbunyi. Ada beberapa siswa dari kelas IV yang bermain-main di depan kelas sebelum bel masuk berbunyi, tetapi ketika sudah terdengar bel masuk mereka segera berlari masuk kelas. Jika ada salah satu siswa yang masuk kelas terlambat maka siswa lain menegurnya salah satunya adalah teman sebangkunya, dengan mengatakan "Wes bel iku cepet-cepet mlebu ndak oleh mainan terus di luar"26

Selain itu juga ketika jam istirahat berlangsung para siswa bergegas keluar kelas tetapi para siswa kelas IV tidak pernah keluar kelas mendahului Ustadzah yang mengajar. Hal ini menunjukkan bahwa mereka sangat menghormati guru Kedisiplinan dan sikap syukur siswa juga ditunjukkan dalam kegiatan sholat Dhuha yang rutin dilaksanakan setiap pagi. Tanpa harus diperintah para siswa kelas IV berjalan dengan rapi menuju aula untuk melaksanakan sholat Dhuha, selama sholat juga tidak tampak siswa yang bermain-main. Hal ini dijelaskan oleh Ustadzah Yunita selaku guru Aqidah Akhlak yang selalu mengawasi kegiatan Sholat Dhuha setiap harinya:

"Kalau sholat anak-anak itu sudah terbiasa tanpa di paksa, jadi setelah berdoa mereka langsung bergegas ke aula untuk sholat. Waktu sholat juga tidak ada siswa yang cengengesan, mungkin kalaupun ada ya cuma satu dua anak, tetapi setelah sholat anak tersebut langsung ditegur agar tidak mengulangi lagi dan anak-anak itu kalau sekali ditegur besoknya udah gak berani lagi" 27

Selama pengamatan, tampak setiap hari siswa sangat akrab dengan Ustadz dan Ustadzah. Ketika jam istirahat para Ustadz ataupun Ustadzah sering mendampingi siswa untuk bermain. Walaupun para siswa sangat dekat dengan Ustadz dan Ustadzah, tetapi mereka tetap sopan dalam berbicara Selalu mengucap salam ketika bertemu, menggunakan bahasa yang halus ketika berbicara. Selain dengan Ustadz dan Ustadzah, para siswa juga selalu menjaga cara berbicara dengan teman sebayanya Mereka bermain dan belajar bersama tanpa saling mengolok atau menjelekkan satu dengan yang lainnya. Hal ini dijelaskan dalam wawancara sebagai berikut:

"Memang kita terbisa sebagai guru harus selalu mendampingi dan mengawasi siswa, meskipun pada jam istirahat kita tetap sesekali memantau siswa, siapa tau ada yang berantem, berkata kotor, atau mengganggu teman yang lainnya. Tapi selama ini jarang sekali ada hal-hal yang menyimpang, kalaupun mereka berantem langsung kita beri arahan agar saling memaafkan. Meskipun antara pengajar dan siswa itu dekat, tapi mereka tetap sopan dan menjaga cara berbicara". ${ }^{28}$

\footnotetext{
${ }^{25}$ Observasi SD Islam Al-Huda Genteng Banyuwangi

${ }^{26}$ Observasi SD Islam Al-Huda Genteng Banyuwangi

${ }^{27}$ Wawancara dengan Ustadzah Yunita (Guru Aqidah Akhlak di SD Islam Al-Huda) Tanggal 17 Juli 2019 jam 11.10 WIB

${ }^{28}$ Wawancara dengan Ustadzah A’yun (Wali Kelas IV SD Islam Al-Huda) Tanggal 17 Juli 2019 jam 11.00 WIB
} 
Selama ini yang bertugas sebagai pemantau karakter siswa adalah wali kelas masingmasing. Sehingga jika ada siswa yang bermasalah maka wali kelas yang pertama kali memberi pengarahan atau mengajak wali dari murid tersebut berdiskusi untuk saling bekerjasama menyelesaikan masalah. Hal ini dikarenakan di SD Islam Al-Huda Genteng Banyuwangi belum memiliki guru BK khusus, sehingga wali kelas juga bertugas menjadi guru BK bagi siswanya.

\section{PEMBAHASAN}

\section{Perencanaan Lingkungan Sebagai Media Pendidikan Karakter Siswa Melalui Kegiatan Ekstrakurikuler dan Kewirausahaan di SD Islam Al-Huda Genteng Banyuwangi}

Kualitas pendidikan dan pembelajaran akan menjadi kunci utama dalam peningkatan kemampuan siswa dalam berintraksi dengan lingkungan. Sedangkan pemebelajaran yang berkualitas merupakan pembelajaran yang terencana dan sengaja diciptakan (intentional learneing) Bukan belajar yang terjadi secara insindental (incindental learning) Gagne menyatkan bahwa pembelajaran adalah serangkaian aktivitas yang sengaja diciptakan dengan maksud untuk memudahkan proses belajar sebagai pengembangan penyampaian informasi dan komuniksasi dengan tujuan yang spesifik, agara pembelajaran yang dilapangan disusun secara sistematis dan akurat. ${ }^{29}$ Akan tetapi purlu sebuah perencanaan yang tepat dalam pemilihan atau penetapan tujuan organisasi atau penentuan strategi, kebijakan, proyek, program, metode, system, anggaran, dan standar yang di perlukan dalam mencapai kesepakatan dalam perencanaan untuk memberikan kejelasan setiap kegiatan yang dilaksanakan secara efisien dan efektif dan berkelanjutan. ${ }^{30}$

Kegiatan yang dilakukan di SD Islam Al-Huda Genteng Banyuwangi guna untuk membentuk karakter siswa agar lebih kreatif, percaya diri, dan rasa cinta terhadap alam Selain itu, terdapat karakter yang tidak terlepas dari identitas sekolah yaitu karakter Islami atau religius. Hal ini dikarenakan SD Islam Al-Huda Genteng Banyuwangi merupakan sekolah berbasis Islam yang berdiri dalam lingkungan Pondok Pesantren Al-Huda Setiap guru diberi keleluasaan berpendapat untuk menentukan kegiatan apa saja yang akan dilakukan pada Kewirausahaan. Dengan berbagai pendapat akan muncul dari beberapa guru, kegiatan yang diusulkan juga harus ada penjelasan makna dan karakter apa yang akan ditanamkan Hanya saja bentuk perencanaan kegiatan yang akan dilakukan tidak tertulis Hanya sebuah arahan dari pihak kesiswaan pada dewan guru.

Seperti halnya perencanaan untuk kegiatan Kewirausahaan yang diselenggarakan pada tanggal 10 Juli 2019. Pihak kesiswaan akan mengumpulakan semua wali kelas dari kelas I sampai VI untuk memberi arahan bagaimana pola kegiatan yang akan dilaksanakan. Arahan pada pihak wali kelas diberikan tiga hari sebelum hari pelaksanaan, untuk meningkatkan kreativitas dan rasa percaya diri siswa maka siswa kelas II dipilih untuk menjadi penjual karena disesuaikan dengan karakter mereka yang aktif dan masih suka bermain. Hal ini berkaitan karena sebagai penjual para siswa harus berani untuk menjajakan barang yang dijual, selain itu juga mereka harus kreatif dalam menata makanan atau minuman yang mereka jual agar dapat menarik pembeli Selanjutnya dari masing-masing wali

29 Barnawi \& M. Arifin, Strategi \& Kebijakan Pembelajaran Pemdidikan Karakter (Jogjakarta: Ar Ruzz Media, 2012), 65.

${ }^{30}$ Rusman, Manajemen Kurukulum, Jakarta: Rajawali Press, 2012, 121. 
kelas akan mejelaskan pada peserta didiknya kegiatan yang akan diadakan untuk mengisi Kewirausahaan.

Pihak sekolah menginginkan agar karakter yang ingin dibentuk tidak hanya sebuah wacana atau teori secara verbal. Maka nilai-nilai tersebut juga disisipkan dalam kegiatan ekstrakurikuler sekolah. Sejalan dengan hal tersebut Ada bebrapa metode yang di tawarkan dalam mengaplikasikan pendidikan karakter di sekolah 1). Metode otonomi dengan menempatkan pendidikan karakter sebagai matapelajaran tersendiri 2). Menyatukan nilainilai karakter sebagai bentuk pembelajaran 3). Ekstra kurikuler melalui sebuah kegiatan tambahan yang berorientasi pembinaan karakter siswa 4). Ilaborasi dengan menggabungkan ketiga metode tersebut dalam seluruh kegiatan sekolah.

\section{Pelaksanaan Lingkungan Sebagai Media Pendidikan Karakter Siswa Melalui Kegiatan Ekstrakurikuler dan Kewirausahaan di SD Islam Al-Huda Genteng Banyuwangi}

Bangsa Indosesia memerlukan sumber daya manusia dalam jumlah dan mutu yang memadai sebagai penggerak pembangunan. Dari sisi jumlah, penduduk Indonesia usia prodiktif telah mencukupi, namun dari mutu perlu ditingkatkan lagi. Sumber daya yang mutu mengacu pada dua hal; Pertama, memiliki kapabilitas yang mecakup (pengertahuan dan keterampilan). Kedua, memiliki karakter yang lebih dalam keilmuanya dan keterampilan yang dimiliki akan bermakna bagi dirinya, masyarakat dan Agama. Hal ini yang membuat SD Islam Al-Huda Genteng Banyuwangi ingin mananamkan karakter pada peserta didiknya agar semua peserta didiknya dapat menjadi manusia yang berilmu dan berkarakter, sehingga mereka mampu menghadapi tantangan dalam bermasyarakat dikemudian hari terdapat gejalagejala yang menandakan tergerusnya karakter bangsa ini. Dilihat dari realita yang ada di masyarakat sudah terkurasnya nilai-nilai karakter anak bangsa karena disebabkan begitu pesatnya perkembangan era teknologi saat ini;

1. Meningkatnya kekerasan di kalangan remaja/masyarakat, kekerasan remaja dan masyarakat akhir-akhir ini sangan meningkat, tawuran antar pelajar membuat orang tua khawatir dan masyarakat menjadi resah, dan banyak kasus tertentu yang dihakimi sendiri menjadi fenomena yang jamak kita temui

2. Mengunakan bahasa dan kata-kata yang kurang enak di dengar, belakangan banyak muncul bahasa alay yang kehadirannya dipicu oleh pola komunikasi dengan SMS yang memiliki keterbatasan karakter

3. Pengeruh pree group (geng) dalam tindak kekerasan menguat kemunculan geng (terutama anak SMA) di kota-kota besar muncul dalam kelompok geng-geng motor

4. Pergiseran perilaku anak bangsa sudah tidak sesuai dengan norma-norma agama yang ada di masyarakat seperti menggunakan narkoba, alkohol, dan seks bebas

5. Moral anak bangsa menjadi baying-bayang sudut pandang relative baik dan buruk bergantung pada siapa dan apa sudut pandangnya. Hal ini sejatinya tidak boleh terjadi karena sesungguhnya baik dan buruk itu sifatya qod'i (pasti) dan diatur dalam berbagai agama

6. Etos kerja yang menurun Etos kerja yang dipicu oleh spirit yang lemah, artinya pemahaman sebagai bentuk ibadah tidak dihayatisatu-satunya ukuran hanyalah uang.

7. Rendahnya rasa hormat anak terhadap orang tua dalam berprilaku Rendahnya hormat pada orang tua dan guru disebabkan oleh banyak faktor: (a) gagalnya orangtua sebagai 
figure bagi anak-anaknya; (b) lingkungan yang tidak kondusif; (c) rendah dalam memahmi agama; (d) orang tua mendidik anak yang kurang atau salah mendidik.

8. Kurang bertanggungjawab individu maupun kelompok

9. Budaya berbohong dan tidak jujur

10. Curiga terhadap sesama

Dari paparan sepuluh tanda merosotnya karakter bangsa, maka SD Islam Al-Huda Genteng Banyuwangi benar-benar memperhatikan pendidikan karakter untuk siswanya Penerapan pendidikan karaktar yang dilakukan salah satunya berupa kegiatan lingkungan, baik lingkungan sekolah maupun lingkungan masyarakat, baik secara langsung maupun tidak langsung. Dari penjelasan pihak kesiswaan, sekolah merupakan elemen penting dalam membentuk karakter siswa, tetapi selain itu juga diperlukan adanya kerjasama dari pihak orangtua serta dukungan dari masyarakat Maka dari itulah sekolah membentuk lingkungan menjadi lingkungan yang berkarakter.

Di SD Islam Al-Huda Genteng Banyuwangi, diadakan sutau pembiasaan dalam rangka membentuk pendidikan karakter siswa Pembiasaan tersebut berupa suatu kegiatan yang dilakukan khusus setiap minggunya. Kegiatan diadakan semenarik mungkin agar siswa tertarik mengikutinya yaitu lingkungan sebagai medianya Jika siswa dapat praktek langsung maka siswa akan lebih tertatik untuk mengikuti. Ketika siswa tertarik dan melakukannya dari hati, maka pesan moral dari kegiatan tersebut akan lebih mudah tersampaikan Beberapa dari kegiatan tersebut adalah Ekstrakurikuler dan Kewirausahaan Ekstrakurikuler dilaksanakan secara rutin setiap hari sabtu dengan materi yang berbeda-beda di setiap minggunya. Sedangkan Kewirausahaan adalah kegiatan khusus untuk mengisi Kewirausahaadan bentuk kegiatan Kewirausahaaakan berbeda-beda di setiap minggunya. Hal ini ditujukan agar kegiatan khusus dalam Kewirausahaa dapat menarik minat siswa, karena kegiatannya yang variataf Dalam pelaksanaan kedua kegiatan ini siswa diajak untuk belajar sambil bermain. Kegiatan dalam lingkungan dibuat semenarik mungkin sehingga siswa tidak merasa jenuh. Dengan diadakan kegiatan yang berkelanjutan diharapkan karakter siswa dapat terbentuk baik secara langsung maupun tidak langsung.

Penjelasan di atas sejalan dengan isi pidato mantan Presiden Susilo Bambang Yudhoyono pada acara peringatan Hardiknas tanggal 11 Mei 2010 di Istana Negara Inti pidato presiden adalah sebagai berikut:

1. Sekolah penting untuk mencipkakan lingkungan yang aerogonomis dan sehat karena kondisi tersebut dapat membentuk susasana belajar yang nyaman dan pikiran yang tidak kacau

2. Nilai-nilai kreatif akan muncul jika didukung oleh lingkungan yang baik

3. Lingkungan yang bersih, asri, dan tertib adalah sebuah budaya yang medukung pendidikan karakter ${ }^{31}$

Dengan memanfaatkan lingkungan maka pendidikan karakter akan lebih mudah tersampaikan Karena siswa tidak akan lepas dari lingkungan Tetapi tidak hanya sebatas lingkungan yang dapat membentuk karakter siswa, pembiasaan-pembiasaan dari kegiatan yang di lakukan di sekolah juga sangat berpengaruh. Dari pembiasaan yang baik maka siswa juga akan mendapat pengalaman belajar yang baik pula Pengalaman belajar inilah yang

31 Rusman, Manajemen Kurukulum, 48. 
diharapkanakan terus diingat dan diterapkan siswa ketika mereka hidup bermasyarakat.

Pembudayaan dan pemberdayaan akan efektif jika dibarengi dengan proses pembiasaan/habituasi Pembiasaan berpedoman pada kebijakan yang diambil, adanya standar baku (pedoman), disesuaikan dengan kondisi lingkungan, dan tentu sumber daya yang dimiliki Pembiasaan tidak berada di uang hampa, tetapi dalam spektrum lingkungan (sekolah / keluarga / masyarakat) sehingga konteksualisasi merupakan sebuah keharusan. ${ }^{32}$

Dalam kegiatan Ekstrakurikuler siswa selalu diarahkan untuk aktif dan kreatif. Terlebih lagi siswa yang mengikuti adalah dari kelas atas, yaitu IV dan V, sehingga mereka sudah mulai dibimbing untuk berfikir kritis seperti dengan pemberian tugas yang harus dikerjakan secara berkelompok. Dengan berkelompok mereka akan belajar untuk menjadi lebih komunikatif Selain itu juga tugas yang diberikan tidak hanya sekedar menjawab pertanyaan, tetapi mereka diminta untuk berdiskusi serta menjelaskan dengan bahasa mereka sendiri. Model kegiatan yang sepeti ini diharapkan dapat menbentuk karakter percaya diri, kreatif, dan kritis). Dapat dilihat dari prakteknya, siswa dituntut untuk aktif mengamati lingkungan yang ada di sekitar sekolah, dengan pengamatan yang dilakukan diharapkan dapat membebtuk karakter cinta alam. Media yang digunakan adalah lingkungan sekolah, hal ini ditujukan agar siswa dapat melihat lingkungan secara langsung, dengan melihat langsung maka mereka akan merasakan rasa yang mereka miliki inilah yang akan menumbuhkan karakter pada diri siswa. Berbeda jika siswa hanya diberikan gambar dan diminta untuk mengamati, karena siswa tidak dapat merasakan dan melihat secara langsung

Ada beberapa cara yang dapat dilksanakan dalam mendidik siswa untuk mengembangkan karakter: ${ }^{33}$

1. Memberikan fasilitas pada siswa dalam melaksankan tugas belajar, diskusi, dan lain-lain untuk memunculkan gagasan baru, baik secara lisan maupun tertulis

2. Memberikan kesempatan untuk berfikir dalam menganalisa, menyelesaikan masalah, dan mengerjakan sesuatu tanpa harus takut

3. Memberikan fasilitas siswa untuk membuat laporan yang dikerjakan baik secara lisan maupun tulisan

4. Memberikan fasilitas siswa dalam menyajikan hasil kerja individu maupun kelompok

Sedangkan untuk kegiatan Kewirausahaan, siswa lebih kepada praktek secara langsung di sekolah. Media yang digunakan adalah lingkungan sosial, yaitu kegiatan jual beli yang ada di masyarakat Media dalam kegiatan ini termasuk dalam pengakaman tiruan, pengalaman ini diperoleh melalui benda-benda atau kejadian-kejadian yang ditiru dari kejadian yang sebenarnya. Dalam pelaksanaannya siswa membuat lingkungan jual beli di sekolah yang menyerupai pasar yang ada di masyarakat, jadi media seperti ini termasuk kegiatan jual beli yang dilakukan dapat memuat siswa merasakan dan mengetahui secara langsung apa yang ada di masyarakat. Hal ini dilakukan dengan cara membuat tiruan pasar di dalam sekolah. Dengan siswa belajar menjadi pedagang diharapkan siswa dapat kreatif dan percaya diri Sedangkan bagi pembeli akan dibentuk karakter jujur, yaitu ketika membeli barang harus membayarnya sesuai harga yang ditawarkan. Dari awal sebelum kegiatan siswa berusaha menata tempat yang akan digunakan untuk berjualan, menyiapkan makanan dan

32 Rusman, Manajemen Kurukulum, 48-49.
33 Rusman, Manajemen Kurukulum, 82-83. 
minuman yang akan di jual, serta menawarkan barang yang dijual pada teman-temannya. Ketika siswa tidak berani untuk menawarkan makanan atau minunan yang dujual maka pembeli tidak akan tertarik untuk mendatangi tempatnya. Sedangakan di akhir kegiatan siswa akan menghitung hasil dari berjualan Siswa akan lebih menghargai uang yang didapatkannya walau hanya sedikit karena itu merupakan hasil kerja keras mereka.

Dengan cara ini pendidikan karakter akan lebih mudah tersampaikan sehingga metode praktek secara langsung di lingkungan yang ada lebih dipilih oleh pendidik di sekolah. Dengan membawa perasaan, cinta, serta pembiasaan amalan kebaikan akan membuat nilai yang akan disampaikan dalam kegiatan Kewirausahaan mudah tersampaikan. Konkretnya, pendidikan karakter pada anak usia dini bisa diwujudkan melalui cara-cara bermain, bercerita, bercakap-cakap, dan dalam jenis penggunaan lingkungan sebagai media pengajaran

\section{Hasil Karakter Siswa Yang Dibentuk Melalui Kegiatan Ekstrakurikuler dan Kewirausahaan}

Karakter yang baik merupakan hal yang selalu diinginkan.Untuk membentuk karakter yang baik maka harus ditanamkan sejak anak masih kecil. Seorang filusuf Yunani bernama Aristoteles mendefinisikan karakter yang baiksebagai kehidupan dengan melakukan tendakan-tindakan yang benar sehubungan dengan diri sendiri dan orang banyak. ${ }^{34}$

Tujuan pendidikan melalui pembelajaran tiada lain yaitu untuk meningkatkan dan mengembangkan kreatifitas dan kualitas sehingga siswa dapat mengetahui bidang-bidang yang dimiliki. Untuk mengetahi perubahan siswa ada tiga aspek pendidikan, yakni kognitif, afektif, dan psikomotorik.

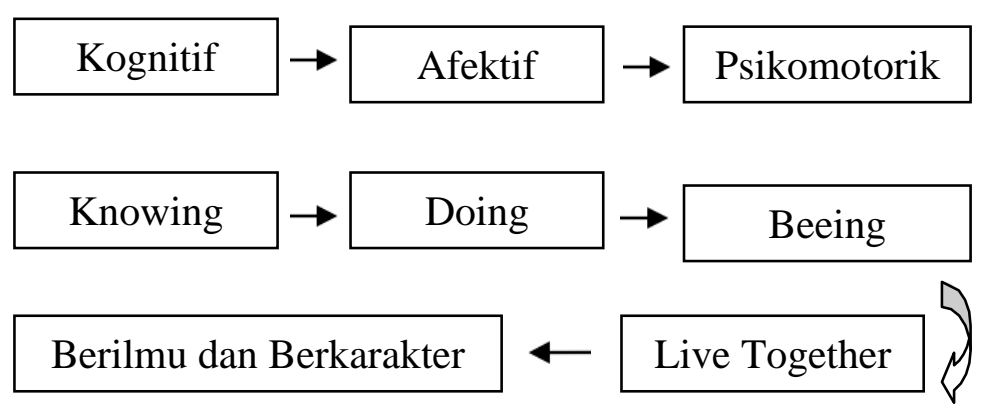

Dari kegiatan yang dilakukan siswa di sekolah harus mendapat dukungan dari pihak keluarga sehingga kegiatan tersebut tercapai. Banyak karakter yang dapat diperoleh dari pendidikan karakter di sekolah, baik yang ditanamkan secara langsun maupun tidak langsung. Berikut tabel karakter yang diperoleh dari kegiatan pemanfaatan lingkungan di SD Islam Al-Huda Genteng Banyuwangi.

Tabel I.

\begin{tabular}{|c|c|}
\hline No & Kegiatan \\
\hline 1 & $\begin{array}{l}\text { - Kewirausahaan merupakan kegiatan lingkungan sosial yang dilaksanakan oleh } \\
\text { siswa untuk menarik masyarakat untuk membeli barang yang dijual siswa. } \\
\text { - Kegiatan jual beli ini ditiru dan dilakukan di dalam sekolah }\end{array}$ \\
\hline
\end{tabular}

${ }^{34}$ Thomas Lickona, Mendidik Untuk Membentuk Karakter, Jakarta: PT Bumi Aksara, 2012, 81. 


\begin{tabular}{|l|l|}
\hline & $\begin{array}{l}\text { - Kewirausahaan termasuk dalam klasifikasi media tiruan. Salah satunya untuk } \\
\text { meningkatkan kreatifitas siswa dalam berwirausaha }\end{array}$ \\
\hline \multirow{2}{*}{$\begin{array}{l}\text { - Ekstrakurikuler salah satu program sekolah yang sering rutin dilaksanakan oleh } \\
\text { siswa setiap hari sabtu. }\end{array}$} \\
- Kegiatan ini diikuti oleh siswa kelas IV dan V selama kegiiatan siswa secara \\
berkelompok melakukan pengamatan di ligkungan sekolah. \\
- Hasil pengamatan akan didiskusikan secara berkelompok dan dilaporkan pada \\
Pembina.
\end{tabular}

Tabel II.

\begin{tabular}{|c|c|}
\hline No & Media \\
\hline 1 & $\begin{array}{l}\text { - Kegiatan Kewirausahaan merupakan kegiatan jual beli yang dilakukan dim } \\
\text { sekolah. Siswa yang bertugas menjadi penjual adalah siswa kelas II, sedangkan } \\
\text { siswa dari kelas lain yang tidak bertugas menjadi penjual adalah sebagai pembeli. } \\
\text { - Selama kegiatan jual beli siswa kelas II menawarkan berbagai barang yang dijual } \\
\text { kepada pembeli. }\end{array}$ \\
\hline 2 & $\begin{array}{l}\text { - Pada kegiatan Ekstrakurikuler media yang digunakan adalah lingkungan alam } \\
\text { yang ada di sekolah. } \\
\text { - Lingkungan alam berkenaan dengan segala sesuatu yang sifatnya alamiah. } \\
\text { Lingkungan alam termasuk pada lingkungan belajar utdoor karena berada di luar } \\
\text { ruangan. } \\
\text { - Lingkungan di sekitar sekolah dapat dipergunakan sebagai media pembelajaran } \\
\text { siswa. }\end{array}$ \\
\hline
\end{tabular}

Tabel III.

\begin{tabular}{|c|c|}
\hline No & Karakter Yang Dibentuk \\
\hline 1 & $\begin{array}{l}\text { Karakter yang dibentuk bagi penjual: } \\
\text { - Percaya diri; penjual berani menawarkan barang yang dijual, penjual harus yakin } \\
\text { bahwa barang yang dijual menarik dan layak untuk dibeli. } \\
\text { - Kreatif; penjual dalam menentukan, memilih, dan membuat barang yang akan } \\
\text { dijual agar pembeli tertarik untuk membelinya. } \\
\text { Karakter yang dibentuk bagi pembeli: } \\
\text { - Jujur; pembeli harus jujur dalam melakukan ransaksi jual beli dengan membayar } \\
\text { sesuai harga yang telah ditentukan walaupun situasi selama kegiatan market day } \\
\text { sangat ramai. }\end{array}$ \\
\hline 2 & $\begin{array}{l}\text { - Rasa cinta alam; siswa mengamati lingkungan sekitar, dengan pengamatan yang } \\
\text { dilakukan tersebut akan membuat siswa lebih memahami bagaimana cara untuk } \\
\text { menjaga dan memelihara lingkungan. } \\
\text { - Komunikatif; diskusi yang dilakukan secara berkelompok akan melatih siswa } \\
\text { untuk berkomunikasi dengan orang lain, selain itu juga melatih siswa untuk bisa }\end{array}$ \\
\hline
\end{tabular}




\begin{tabular}{|l|l|}
\hline - Syukur; dalam segala kegiatan yang dilakukan akan didasarkan pada syariat Islam, \\
seperti dalam pembentukan kelompok juga dipisahkan antara kelompok putra dan \\
kelompok putri. Hal ini menandakan bahwa dalam pergaulan ada batasan jika \\
bukan muhrim. sehingga nilai Islami tidah hanya ada dalam pelajaran agama tetapi \\
juga ditanamkan dalam segala hal. Selain itu dengan memahami lingkungan maka \\
siswa akan lebih mensyukuri karunia Allah dan senantiasa menjaga serta \\
melestarikannya. \\
Disiplin, setiap tugas yang dikumpilkan harus tepat waktu. Jika melakukan \\
pelanggaran maka akan mendapat hukuman
\end{tabular}

Salah satu indikator keberhasilan pendidikan karakter siswa dapat mengamalkan dan mengerjakan ajaran agama yang sesuai dengan tahapan perkembangan usia siswa. Tanda yang tampak bagi seseorang yang beragama dengan baik adalah mengamalkan ajaran agama yang dianut dalam kehidupan sehari-hari. Inilah karakter yang sesungguhnya dibangun bagi penganut agama. Di dalam Islam, misalnya, keimanan seseorang baru dianggap sempurna bila meliputi tiga hal, yakni keyakinan di dalam hati, diikrarkan secara lisan, dan diwujudkan dalam perbuatan nyata. Demikian pula dengan anak didik kita, hendaknya dapat mengamalkan ajaran agama yang dianutnya. Apabila dapat dekerjakan dengan baik, berarti pendidikan karakter telah berhasil dibangun dalam proses belajar di sekolah. ${ }^{35}$

Setiap hari siswa harus melakukan berbagai aktivitas baik dalam kegiatan belajar maupun di luar jam pelajaran. Siswa selalu aktif dalam segala hal, siswa selalu percaya diri. ketika siswa tidak paham dengan materi yang diajarkan tanpa ragu mereka bertanya pada Pembina. Dalam kegiatan belajar para siswa harus selalu aktif bertanya sehingga suasana kelas menjadi aktif dan tidak pasif.

Indikator penting berkaitan dengan telah berhasilnya pendidikan karakter pada anak didik dikemabangkan adalah menunjukkan sikap percaya diri. Sikap percaya terbangun dengan cara berpikir yang positif dalam menghadapi kehidupan. Inilah kunci sukses setiap usaha yang dikerjakan manusia. Tidak percaya diri, seseorang hanya selalu dihantui keraguraguan dalam melangkah sehingga menyebabkan kegagalan dalam mengerjakan. Oleh karena itu anak didik perlu dibangun jiwanya agar mempunyai kepercayaan diri yang baik. Salah satu cara yang terbaik adalah membangun keyakinan kedapaTuhan Yang Maha Esa. ${ }^{36}$

SD Islam Al-Huda Genteng Banyuwangi merupakan sekolah alam yang didesain khusus bagi siswa agar siswa nyaman melakukan segala aktivitas di sekolah. Dikarenakan ini merupakan sekolah alam, sehingga sekolah ini memanfaatkan lingkungan sekolah sebagai media dalam berbagai hal. Siswa merasa ikut memiliki sekolah sehingga mereka juga merasa bertanggung jawab untuk menjaga kenyamanan sekolah. Para siswa selalu tertib di sekolah dan mematuhi peraturan yang ada di sekolah. Seperti tidak membuang sampah di sembarang tempat, tidak mencoret-coret saung-saung yang ada di sekolah. Walaupun ketika jam istirahat berlangsung siswa banyak yang bermain di saung ataupun halaman sekolah, tetapi lingkungan sekolah tetap terjaga kebersihannya.

\footnotetext{
${ }^{35}$ Azzet, Akhmad Muhaimin, Urgensi Pendidikan Karakter Di Indonesia, Jogjakarta: Ar Ruzz Media, $2011,68$.

${ }^{36}$ Azzet, Akhmad Muhaimin, Urgensi Pendidikan Karakter Di Indonesia, 69
} 
Karakter yang paling penting dalam kehidupan yang berkelanjutan dengan generasi mendatang adalah memanfaatkan lingkungan secara bertanggung jawab. Hal ini penting untuk diperhatikan sebab jangan sampai terjadi memanfaatkan lingkungan dengan cara yang serakah, kekayaan alam dikeruk sebanyak-banyaknya tanpa memperhatikan kepentingan generasi mendatang, hutan dibabat habis tanpa melakukan penanaman kembali yang memadai, atau meninggalkan bekas pertambangan dengan lingkungan yang berantakan dan tidak bisa dimanfaatkan kembali. Sungguh kesadaran untuk bisa memanfaatkan lingkungan secara bertanggung jawab ini harus dikembangkan pada setiap anak didik dalam pendidikan kita. Tanpa kesadaran yang semacam ini, Indonesia yang terkenal subur makmur akan menjadi tandus dan terpuruk dalam kemiskinan. ${ }^{37}$

\section{KESIMPULAN}

Media yang digunakan dalam pembentukan pendidikan karakter di SD Islam Al-Huda adalah lingkungn. Lingkungan alam sebagai media pembentukan pendidikan karakter siswa dalam kegiatan Ekstrakurikuler. Sedangkan lingkungan sosial sebagai media dalam pembentukan pendidikan karakter siswa melalui kegiatan Kewirausahaan. Dalam pelaksanaan kegiatan Ekstrakurikuler, siswa mendapat pemahaman materi tentang makna dari surat Al Alaq dan kaitannya dengan lingkungan sekitar. Karakter yang ditanamkan pada kegiatan ini adalah rasa cinta alam, komunikatif, dan religius. Media yang digunakan adalah lingkungan alam, siswa mengamati dan memberi solusi terhadap masalah yang ditemui selama melakukan pengamatan. Sedangkan pada pelaksanaan Kewirausahaan, lingkungan sosial sebagai media pembentukan pendidikan karakter. Siswa melakukan jual beli seperti kegiatan jual beli yang dilakukan di masyarakat. Pelaksanaan kegiatan semacam ini termasuk dalam klasifikasi media pengalaman tiruan. Karakter yang didapat dari kegiatan ini adalah percaya diri, kreatif, dan jujur.

Karakter yang diperoleh dari kegiatan Ekstrakurikuler adalah disiplin, cinta alam, komunikatif, dan syukur. Sedangkan karakter yang diperoleh dari pemanfaatan lingkungan sebagai media pembentukan pendidikan karakter melalui kegiatan Kewirausahaan adalah percaya diri, kreatif, dan jujur. Karakter yang terbentuk dari kegiatan lingkungan sebagai media ini diharapkan dapat terus dimiliki siswa dan di terapkan dalam kehidupan bermasyarakat.

\section{DAFTAR PUSTAKA}

Azzet, Akhmad Muhaimin, 2011, Urgensi Pendidikan Karakter Di Indonesia, Jogjakarta: ArRuzz Media.

Barnawi \& M. Arifin, 2012, Strategi \& Kebijakan Pembelajaran Pemdidikan Karakter, (Jogjakarta: Ar Ruzz Media).

Darmadi Hamid, 2011, Metode Penelitian Pendidikan, (Pontianak: Alfabeta).

Fadillah Mohammad \& Mualifatul Khorida Lilif, 2013, Pendidikan Karakter Untuk Anak Usia Dini, (Jogjakarta: Ar-Ruzz Media).

Jusuf Soewadji, 2012, Pengantar Metodologi Penelitian, Jakarta: Mitra Wacana Media. Moleong Lexy, 2002, Metode Penelitian Kualitatif (Bandung: PT Remaja Rosda Karya).

\footnotetext{
${ }^{37}$ Azzet, Akhmad Muhaimin, Urgensi Pendidikan Karakter Di Indonesia, 78.
} 
Jurnal Tinta, Vol. 1 No. 2, September 2019, Hal. 73-92

Rusman, 2012, Manajemen Kurukulum, Jakarta: Rajawali Press.

UU Nomor 29 Tahun 2003 tentang Sistem Pendidikan Nasional.

Thomas Lickona, 2012, Mendidik Untuk Membentuk Karakter, Jakarta: PT Bumi Aksara. 